\title{
Growth, Yield and Water Use Efficiency of Groundnut under Drip and Surface Furrow Irrigation
}

\author{
P. Sri Ranjitha*, V. Ramulu, G. Jayasree and S. Narender Reddy \\ Department of Agronomy, PJTSAU, Hyderabad, Telangana, India \\ *Corresponding author
}

A B S T R A C T

\begin{abstract}
\begin{tabular}{|l|}
\hline K e y w o r d s \\
$\begin{array}{l}\text { Groundnut, Growth, } \\
\text { Yield, Drip Irrigation, } \\
\text { Water use efficiency, } \\
\text { IW/CPE }\end{array}$ \\
\hline Article Info \\
\hline $\begin{array}{l}\text { Accepted: } \\
\text { 10 August } 2018 \\
\text { Available Online: } \\
\text { 10 September } 2018\end{array}$ \\
\hline
\end{tabular}
A field experiment was conducted to investigate the effect of drip and surface furrow irrigation on growth, yield and water use efficiency of groundnut to at College Farm, Rajendranagar. The experiment consisted of six irrigation treatments i.e., $\mathrm{I}_{1}=0.4$ Epan, $\mathrm{I}_{2}=$ 0.6 Epan, $\mathrm{I}_{3}=0.8$ Epan, $\mathrm{I}_{4}=1.0$ Epan, $\mathrm{I}_{5}=1.2$ Epan through drip system and $\mathrm{I}_{1}=$ Surface furrow irrigation at 1.0 IW/CPE ratio replicated four times. The results revealed that among drip irrigation levels, plant growth traits, yield attributing characters and yield of groundnut increased significantly at each higher levels of drip irrigation from 0.4 Epan $\left(1234 \mathrm{~kg} \mathrm{ha}^{-1}\right)$ up to 1.0 Epan $\left(4005 \mathrm{~kg} \mathrm{ha}^{-1}\right)$ and further increasing irrigation level to 1.2 Epan resulted in yield reduction (3801 $\left.\mathrm{kg} \mathrm{ha}^{-1}\right)$. However, economic yield with optimum water use was obtained when irrigation was scheduled at 0.8 Epan $\left(3765 \mathrm{~kg} \mathrm{ha}^{-1}\right)$. Water use efficiency was found to be higher when suboptimal drip irrigation scheduled at 0.8 Epan $\left(21.0 \mathrm{~kg} \mathrm{ha} \mathrm{mm}^{-1}\right)$ compared to rest of the schedules. Hence, this study reveals that maximum yield can be achieved with minimum quantity of water application through appropriate irrigation method (drip method) compared to surface irrigation under scarce situation.
\end{abstract}

\section{Introduction}

Irrigation water is one of the most critical input for agriculture that is scarce and expensive. To increase the productivity, the major input i.e., water plays a very important role in any production system. And it is already known fact that the fresh water availability is decreasing day-by-day and the share of water to agriculture is diminishing sharply. To meet the demand of ever increasing population, and changing living standards and dietary needs, we need to produce more and more cereals/pulses/oilseeds. Another major changing consumption pattern in urban areas is of use of more and more non-vegetarian dishes, which in turn requires to product more and more these crops to feed chick and animals which requires all these food in balanced proportion. Various organizations estimate that a $70-100 \%$ increase in these food crops production is required over the next 25 - 30 years. There is also a common understanding that $80-90 \%$ of this increase will have to come from existing cultivated land and only 10 - 20\% from land reclamation. However, due to urbanization, desertification, 
salinization, etc. the cultivated area is in fact decreasing. Thus, an efficient alternative is to adopt new technologies such as drip irrigation and sprinkler irrigation systems to close growing field crops too and one such effort in groundnut is carried out to see the production potential of the crop under drip system of irrigation compared to existing surface furrow irrigation.

\section{Materials and Methods}

The present study was conducted at College Farm, PJTSAU (situated at an altitude of $542.6 \mathrm{~m}$ above MSL and $17^{\circ} 19^{\prime} 16.4$ " $\mathrm{N}$ latitude and $78^{\circ}$ 23' 43.7' E longitudes), Rajendranagar, Hyderabad, Telangana during rabi season of 2013-14. Rainfall of $282.2 \mathrm{~mm}$ was received during the crop growing period in 11 rainy days which were distributed in the first two months only. The soil was sandy loam in texture with low in available nitrogen $(142.8 \mathrm{~kg} / \mathrm{ha})$ and high in available phosphorus (27.28 kg/ha) and high in available potassium $(345 \mathrm{~kg} / \mathrm{ha})$ contents with $\mathrm{pH}$ of 7.8. The experiment was laid in randomized block design with four replications. The treatments consisted of six irrigation levels i.e., drip irrigation at 0.4 Epan, drip irrigation at 0.6Epan, drip irrigation at 0.8 Epan, drip irrigation at 1.0 Epan, and drip irrigation at 1.2 Epan and a surface furrow irrigation at 1.0 IW/CPE.

The total amount $146.6 \mathrm{~mm}, 199.9 \mathrm{~mm}, 253.3$ $\mathrm{mm}, 306.7 \mathrm{~mm} 360.1 \mathrm{~mm}$ and $299.8 \mathrm{~mm}$, respectively of seasonal irrigation water was applied on every alternate day in drip irrigated treatments and in surface furrow $5.0 \mathrm{~cm}$ depth of irrigation water was given when Epan reaches $50 \mathrm{~mm}$. Recommended dose of $30 \mathrm{~kg}$ nitrogen, $50 \mathrm{~kg} \mathrm{P}_{2} \mathrm{O}_{5}$ and $50 \mathrm{~kg} \mathrm{~K}_{2} \mathrm{O} /$ ha were applied through fertigation with variable ratios up to peak growth period. In case of surface furrow irrigation farmer practice of fertilizer application (entire $\mathrm{P}_{2} \mathrm{O}_{5}$ and $\mathrm{K}_{2} \mathrm{O}$ along with
$50 \%$ of $\mathrm{N}$ as basal and remaining $\mathrm{N}$ in two equal splits i.e., at flower initiation stage) was applied. The sources of $\mathrm{N}, \mathrm{P}_{2} \mathrm{O}_{5}$ and $\mathrm{K}_{2} \mathrm{O}$ for fertigation were Urea, Mono Ammonium Phosphate (MAP) and Potassium Nitrate $\left(\mathrm{KNO}_{3}\right)$ and for surface furrow irrigation it was urea, Di-Ammonium Phosphate (DAP) and Muriate of Potash (MoP). Drip laterals were laid out at $0.8 \mathrm{~m}$ apart with inline emitters at $0.4 \mathrm{~m}$ apart on lateral pipe. The discharge rate was $2 \mathrm{~L} \mathrm{~h}^{-1}$ from each emitter. Groundnut variety (Kadiri-6) was sown on $17^{\text {th }}$ October 2013 and harvested on $23^{\text {rd }}$ February 2014. The sowing was done manually with a spacing of $30 \mathrm{~cm} \mathrm{X} 10 \mathrm{~cm}$ by dibbling method.

\section{Results and Discussion}

\section{Growth parameters}

The growth parameters viz., plant height, leaf area index, number of branches and dry matter productions of groundnut were significantly affected by varying levels of drip and surface irrigation. Increase in average plant height, leaf area index, number of branches and dry matter productions of groundnut was rather slow up to 30 days after sowing thereafter it increased linearly up to $60 \mathrm{DAS}$, and after that although plant height was continued to increase until maturity $(26.86 \mathrm{~cm})$ it was at a decreasing rate and negligible. On the other hand, leaf area index reduced drastically (0.81) due to senescence of the older leaves but the total dry matter was continued to increase (732.5 g) until the harvest of the crop (Table 1). Drip irrigation had resulted in significantly higher plant height, leaf area index, number of branches and dry matter production over surface furrow irrigation at 1.0 IW/CPE ratio in all the growth stages of groundnut. However, the effect of drip irrigation levels on these parameters was not significantly marked in the course of early growth period of the crop (up to 30 DAS), 
since the irrigation treatments were imposed only after 15 DAS. Significantly higher plant height was recorded in drip irrigation treatments over surface furrow irrigation treatments at all growth stages wherein surface furrow irrigation at 1.0 IW/CPE was on par with drip irrigation at 0.6 Epan at all the crop growth stages. Among the drip irrigation, drip irrigation scheduled at 1.2 Epan recorded superior plant height over other treatments except that the difference between 0.8 and 1.0 Epan was not significant. Significantly lowest plant height was recorded with the drip irrigation at 0.4 Epan during all the crop growth stages.

Leaf area index was significantly higher in drip irrigated groundnut (1.0 and 1.2 pan evaporation replenishment) as compared to surface check basin irrigation at 1.0 IW: CPE ratio and other levels of drip irrigation scheduling. Irrigations at each higher level of evaporation replenishment from 0.6 to 1.2 Epan produced significantly higher leaf area index over its lower irrigation level except that the difference between 1.0 and 1.2 Epan was statistically not significant at all the growth stages. Significantly the lowest LAI was recorded with drip irrigation scheduled at 0.4 Epan at all growth stages except that the difference in LAI between 0.4 Epan and 0.6 Epan at 90 DAS was not significant. Drip irrigation scheduled at 0.8, 1.0 and 1.2 Epan produced significantly higher dry matter $/ \mathrm{m}^{2}$, which were statistically on par and significantly superior over 0.4 and 0.6 Epan and surface furrow irrigation at $1.0 \mathrm{IW} / \mathrm{CPE}$ ratio. The difference in dry matter production between 0.6 Epan and 1.0 IW: CPE ratio was significant except at 60 DAS the difference in dry matter production between 0.6 Epan and 1.0 IW: CPE ratio was not significant and it was in the decreasing order of 1.0 IW: CPE> 0.6 Epan> 0.4 Epan treatments. The lowest dry matter production was registered in drip irrigated crop at 0.4 Epan.
Among drip irrigation levels scheduling irrigations at each higher level of evaporation replenishment from 0.4 to 1.2 Epan produced higher number of branches plant ${ }^{-1}$ except that the difference between 0.8, 1.0 and 1.2 Epan was statistically not significant at all the growth stages (60 and 90 DAS and at harvest).

At all the crop growth stages the number of branches plant ${ }^{-1}$ in surface furrow irrigation at 1.0 IW/CPE and drip irrigation scheduled at 0.4 and 0.6 Epan were statistically on par.

The increased plant height, leaf area index and dry matter production with increase in drip irrigation level could be traced to favorable soil water balance maintained in the crop root zone depth. Further, higher frequency of irrigation and increased availability of soil moisture under drip irrigation might have led to effective absorption and utilization of available nutrients and better proliferation of roots resulting in quick canopy growth.

An optimal soil and plant water balance under drip irrigation scheduled at 0.6, 0.8, 1.0 and 1.2 Epan treatments might have stimulated increased activity of meristematic cells and cell elongation of internodes resulting in higher growth rate of stem in turn promoting higher plant height (Gardner et al., 1985 and Vijaykumar, 1999).

The higher LAI could be attributed to maintenance of higher soil water potential constant availability of nutrients which resulted in better translocation of photosynthates and more carbohydrate synthesis contributing to favorable plant water balance as compared to the crop with deficit water supply in 0.4, 0.6 Epan through drip and surface furrow irrigation at $1.0 \mathrm{IW} / \mathrm{CPE}$ (Constable and Hodgson, 1990), since water plays a vital role in carbohydrate metabolism, protein synthesis, cell wall synthesis and cell enlargement (Sampath kumar et al., 2006). 
Table.1 Plant height $(\mathrm{cm})$, Leaf area index and Dry matter production $\left(\mathrm{g} / \mathrm{m}^{2}\right)$ as influenced by irrigation levels (drip and surface furrow) at different crop growth stages

\begin{tabular}{|c|c|c|c|c|c|c|c|c|c|c|c|c|}
\hline \multirow[t]{2}{*}{ Treatment } & \multicolumn{4}{|c|}{ Plant height (cm) } & \multicolumn{4}{|c|}{ Leaf Area Index } & \multicolumn{4}{|c|}{ Dry matter production $\left(\mathrm{g} \mathrm{m}^{-2}\right)$} \\
\hline & $\begin{array}{c}30 \\
\text { DAS }\end{array}$ & $\begin{array}{c}60 \\
\text { DAS }\end{array}$ & $\begin{array}{c}90 \\
\text { DAS }\end{array}$ & $\begin{array}{c}\text { At } \\
\text { harvest }\end{array}$ & $\begin{array}{c}30 \\
\text { DAS }\end{array}$ & $\begin{array}{c}60 \\
\text { DAS }\end{array}$ & $\begin{array}{c}90 \\
\text { DAS }\end{array}$ & $\begin{array}{c}\text { At } \\
\text { harvest }\end{array}$ & $\begin{array}{c}30 \\
\text { DAS }\end{array}$ & $\begin{array}{c}60 \\
\text { DAS }\end{array}$ & $\begin{array}{c}90 \\
\text { DAS }\end{array}$ & $\begin{array}{c}\text { At } \\
\text { harvest }\end{array}$ \\
\hline Drip irrigation at 0.4 Epan & 10.39 & 15.77 & 23.37 & 23.91 & 0.99 & 2.23 & 1.89 & 0.40 & 65.55 & 102.60 & 221.38 & 352.17 \\
\hline Drip irrigation at 0.6 Epan & 10.54 & 17.69 & 24.07 & 24.39 & 0.89 & 2.82 & 2.04 & 0.74 & 72.30 & 119.76 & 391.22 & 532.28 \\
\hline Drip irrigation at 0.8 Epan & 11.78 & 20.84 & 27.14 & 27.88 & 1.19 & 3.56 & 3.07 & 0.85 & 96.48 & 221.54 & 607.50 & 881.54 \\
\hline Drip irrigation at 1.0 Epan & 12.01 & 21.12 & 27.37 & 28.15 & 1.04 & 4.04 & 3.93 & 1.06 & 105.20 & 252.17 & 651.16 & 969.47 \\
\hline Drip irrigation at 1.2 Epan & 11.04 & 22.17 & 29.17 & 30.21 & 1.44 & 3.93 & 3.79 & 0.98 & 99.50 & 228.86 & 625.15 & 927.62 \\
\hline $\begin{array}{c}\text { Surface furrow irrigation } \\
\text { at } 1.0 \mathrm{IW} / \mathrm{CPE} \\
\end{array}$ & 10.84 & 18.78 & 26.40 & 26.63 & 1.23 & 2.93 & 2.84 & 0.83 & 89.20 & 144.18 & 482.82 & 732.20 \\
\hline SEm \pm & 0.76 & 0.62 & 0.76 & 1.01 & 0.13 & 0.11 & 0.23 & 0.06 & 3.15 & 8.86 & 17.26 & 51.43 \\
\hline $\mathrm{CD}(\mathrm{P}=0.05)$ & NS & 1.97 & 2.41 & 3.19 & NS & 0.33 & 0.73 & 0.19 & 9.92 & 27.91 & 54.40 & 162.07 \\
\hline Mean & 11.1 & 19.39 & 26.25 & 26.86 & 1.13 & 3.25 & 2.93 & 0.81 & 88.04 & 178.18 & 496.54 & 732.54 \\
\hline
\end{tabular}

Table.2 Number of pods plant ${ }^{-1}$, kernels pod ${ }^{-1}$, pod yield $\left(\mathrm{kg} \mathrm{ha}^{-1}\right)$ and Water use efficiency $(\mathrm{kg} \mathrm{ha} / \mathrm{mm})$ of groundnut as influenced by irrigation levels (drip and surface furrow)

\begin{tabular}{|c|c|c|c|c|}
\hline Treatment & $\begin{array}{l}\text { Number of } \\
\text { pods plant }^{-1}\end{array}$ & $\begin{array}{l}\text { Number of } \\
\text { kernels pod }^{-1}\end{array}$ & $\begin{array}{l}\text { Pod yield (kg } \\
\text { ha }^{-1} \text { ) }\end{array}$ & $\begin{array}{l}\text { Water use efficiency } \\
\qquad(\mathrm{kg} \mathrm{ha} / \mathrm{mm})\end{array}$ \\
\hline Drip irrigation at 0.4 Epan & 11.78 & 1.43 & 1234 & 8.0 \\
\hline Drip irrigation at 0.6 Epan & 13.11 & 1.52 & 2129 & 12.6 \\
\hline Drip irrigation at 0.8 Epan & 22.11 & 1.82 & 3765 & 21.0 \\
\hline Drip irrigation at 1.0 Epan & 24.78 & 1.87 & 4005 & 19.9 \\
\hline Drip irrigation at 1.2 Epan & 21.78 & 1.80 & 3801 & 17.8 \\
\hline Surface furrow irrigation at $1.0 \mathrm{IW} / \mathrm{CPE}$ & 17.11 & 1.67 & 2436 & 10.6 \\
\hline $\begin{array}{c}\text { SEm } \pm \\
\end{array}$ & 1.11 & 0.05 & 184.09 & \\
\hline $\mathrm{CD}(\mathrm{P}=0.05)$ & 3.49 & 0.15 & 584.07 & \\
\hline Mean & 18.44 & 1.68 & 2894.85 & \\
\hline
\end{tabular}


Dry matter accumulation in groundnut is a result of leaf and stem growth during vegetative phase and a combination of pod and kernel growth concurrent with shifts in leaf and stem mass during reproductive phase. Therefore, these parameters had profound influence on final dry matter production. Water availability can influence stem elongation i.e., plant height, number of branches plant ${ }^{-1}$ and size of individual leaves and number, hence, more LAI and in turn higher dry matter production (Candido et al., 2000, Hebbar et al., 2004).

\section{Yield parameters and yield}

The influence of drip irrigation on pods/plant, kernels/ pod and pod yield over surface furrow irrigation is presented in Table 2. The mean pods/plant, kernels / pod and pod yield was $18.44,1.68$ and $2894 \mathrm{~kg} / \mathrm{ha}$, respectively.

Optimum irrigation water application had enormous influence on enhancing the number of pods plant ${ }^{-1}$.Significantly higher number of pods plant $^{-1}$ were recorded by groundnut when drip irrigation was scheduled at 1.0 Epan (24.78) and superior over 0.4, 0.6 Epan and surface furrow irrigation at $1.0 \mathrm{IW} / \mathrm{CPE}$ treatments but was on par with drip irrigation scheduled at 0.8, 1.2 Epan. Optimum irrigation water application had enormous influence on enhancing the number of pods plant $^{-1}$. Significantly higher number of pods plant $^{-1}$ were recorded by groundnut when drip irrigation was scheduled at 1.0 Epan (24.78) and superior over 0.4, 0.6 Epan and surface furrow irrigation at $1.0 \mathrm{IW} / \mathrm{CPE}$ treatments but was on par with drip irrigation scheduled at 0.8 , 1.2 Epan.

The number of pods plant ${ }^{-1}$ is an important yield attribute that finally contributes to the pod yield $\mathrm{ha}^{-1}$. Because of frequent irrigation under drip treatment might have created favorable moisture conditions for the crop growth consequently increased the values of the yield attributes than other treatments (surface furrow irrigation) (Patel et al., 2009 and Shaikh et al., 2004).
The crop in drip irrigation scheduled at 1.0 Epan had significantly higher number of seeds $\operatorname{pod}^{-1}$ (1.87) over drip irrigation scheduled at $0.4,0.6$ Epan and surface furrow irrigation at 1.0 IW/CPE ratio treatments except that it was statistically on par with 0.8 and 1.2 Epan.

Drip irrigation scheduled at 1.0 Epan all throughout the crop growth period recorded significantly higher pod yield (4005 kg ha-1) over drip irrigation at 0. 4 Epan, 0.6 Epan and surface furrow irrigation at $1.0 \mathrm{IW} / \mathrm{CPE}$ ratio. However, the pod yield noticed with drip irrigation at 0.8 Epan and 1.2 Epan were on par with drip irrigation scheduled at 1.0 Epan. On the other hand, deficit irrigation at 0.4 Epan and 0.6 Epan throughout the crop growth period caused significant reduction in pod yield relative to higher level of drip irrigations.

The lowest grain yield was recorded in 0.4 Epan drip irrigation treatment. The above trends in grain yield levels registered under $0.8,1.0$ and 1.2 Epan in comparison to other treatments could be traced to the favorable soil water balance (effective rainfall + applied water) as was observed by variation in soil moisture during the crop growing season and through variation in $\mathrm{ETc} / \mathrm{ETo}$ ratios (i.e., Kc values) under drip and surface furrow irrigation treatments. Similar results were reported by Hebbar et al., (2004) Banyopadhyay et al., (2005) Sampath kumar et al., (2006) and Veeraputhiran et al., (2002) Selvaraj et al., (1997). The maintenance of continuously high soil water potential, thus minimizing wide fluctuations in soil water content during the irrigation cycle, is an important and advantageous feature of drip irrigation (Bresler, 1977 and Bar-Yosef, 1999).

\section{Water use efficiency}

Increase in irrigation levels increased the water use efficiency (upto 0.8 Epan) owing to increase in the seed yield. Further increase in the irrigation levels over and above 0.8 Epan resulted in declining water use efficiency of groundnut crop. There was a remarkable 
difference in water use efficiency observed between drip irrigation scheduled at 1.0 Epan $\left(19.9 \mathrm{~kg} \mathrm{ha}^{\left.-\mathrm{mm}^{-1}\right)}\right.$ and surface furrow irrigation scheduled at $1.0 \mathrm{IW} / \mathrm{CPE}$ ratio (10.6 kg ha$\mathrm{mm}^{-1}$ ). Even drip irrigation scheduled at 0.6 Epan recorded higher water use efficiency than the surface furrow irrigation. This could be due to the fact that the yield levels produced are in proportionate to water used by the crop.

\section{References}

Banyopadhyay, P. K., Mallick, S. and Rana, S. K., 2005, Water balance and crop coefficient of summer grown peanut (Arachis hypogaea L.) in humid tropical region of India. Irrig. Sci., 23: 161-169.

Bar-Yousef, B. 1999. Advances in fertigation. Advances in Agronomy. 65: 1.

Bresler E. 1977. Trickle-drip irrigation: Principles and application to soil-water management. Advances in Agronomy. 29: 343-393.

Candido, V., Miccolis, V and Perniola, M. 2000. Effects of irrigation regime on yield and quality of processing tomato (Lycopersicon esculentum Mill.) cultivars. Proceedings of III International Symposium on Irrigation of Horticultural Crops, Potenza, Italy. Acta Horticulture. 537: 779-788.

Constable, G.A and Hodgson, A.S. 1990. Comparison of drip and furrow irrigated cotton on cracking clay soil. Growth and nutrient uptake. Irrigation Science. 11:137-142.

Gardner, F.P., Pearu, R.B and Mitchell, R.L. 1985. Physiology of crop plants. Iowa State University press. Iowa. 327.
Hebbar, S. S., Ramachandrappa, B. K., Nanjappa, H. V. and Prabhakar, M., 2004, Studies on NPK drip fertigation in field grown tomato (Lycopersicon esculentum Mill.). Europ. J. Agron., 21:117-127.

Patel, G. N., Patel, P. T., Patel, P. H., Patel, D. M., Patil, D. K and Patil, R. M. 2009. Yield attributes, yield, quality and uptake of nutrients by summer groundnut (Arachis hypogaea L.) as influenced by sources and levels of sulphur under varying irrigation schedules. Journal of Oilseeds Research. 26(2): 119-122.

Sampath Kumar, T. S., Krishnasamy, S., Ramesh, K. and Shanmugasundaram., 2006, Effect of drip and surface irrigation methods with rice straw mulch on productivity and water use efficiency of summer cotton. Crop Res., 32(2): 141144.

Selvaraj, P. K., Asokaraja, N. And Manicksundaram, P., 1997, Drip fertigation for sugarcane. Indian Farming. pp: 17-21.

Shaikh, A. A., Nimbalkar, C. A and Jawale, S. M. 2004. Effect of irrigation scheduling and mulches on yield and yield contributing characters of summer groundnut. Journal of Maharashtra Agricultural Universities. 29(2): 163-166.

Veeraputhiran, R., 2002, Drip fertigation studies in hybrid cotton. Ph.D. Thesis. Tamil Nadu Agric. Univ. Coimbatore.

Vijaykumar, B. 1999. Plant-water relations and yield of sunflower (Helianthus annuus L.) and mustard (Brassica juncea L.) as influenced by water deficits. Ph.D (Agri.) thesis submitted to ANGRAU, Hyderabad.

\section{How to cite this article:}

Sri Ranjitha, P., V. Ramulu, G. Jayasree and Narender Reddy, S. 2018. Growth, Yield and Water Use Efficiency of Groundnut under Drip and Surface Furrow Irrigation. Int.J.Curr.Microbiol.App.Sci. 7(09): 1371-1376. doi: https://doi.org/10.20546/ijcmas.2018.709.164 